\title{
THE ROLE OF HIGHER EDUCATION POLICY AND THE DEVELOPMENT OF MANAGEMENT SCIENCE IN THE INDUSTRIAL REVOLUTION 4.0: A PERSPECTIVE FROM INDONESIA
}

\author{
Yudha Dwi Nugraha \\ Departemen Manajemen, Universitas Islam Bandung \\ Jl. Tamansari No.1, Tamansari, Kec. Bandung Wetan, Kota Bandung, Jawa Barat 40116 \\ Email: yudhadwinugraha@unisba.ac.id
}

\begin{abstract}
The development of digital technology has disrupted a variety of human activities, not only as a driving force for the economy but also in the fields of science and technology and higher education. The industrial revolution $4.0 \mathrm{era}$ has influenced higher education policy, teaching, and development of management science in universities. This article focuses to discuss the role of higher education policy and the development of management science in the era of industrial revolution 4.0. Based on theoretical studies and relevant literature reviews, the author argued that the challenges of the industrial revolution 4.0 must be responded quickly and appropriately by all stakeholders to be able to anticipate changes in the world and increase the competitiveness of the Indonesian college student in the midst of global competition. The management science curriculum development must emphasize the fields of Science, Technology, Engineering, and Mathematics. Management science should refer to learning based on information and communication technology, the internet of things, big data, and computerization. Furthermore, management science is expected to create higher thinking order skills (HOTS) for higher education students. Finally, management science is also expected to provide teaching and have noble values, spiritual values, wisdom, and the element of human touch.
\end{abstract}

Keywords: STEM; HOTS; Management science; Higher education policy.

\section{INTRODUCTION}

The world has now entered the era of the industrial revolution 4.0 marked by increased connectivity, interaction and development of digital systems, visual and artificial intelligence. The world is now also open and without limits, where everyone is easy to interact and communicate. This arises because of the phenomenon of globalization that makes a global life. The phenomenon that opens up new opportunities in efforts to build and improve the lives of the people and nation. The development of the industrial revolution 4.0 uses intelligence engineering and the internet of things as coffers of movement and connectivity between humans and machines. The term industry 4.0 itself originated from the idea of the fourth industrial revolution in which the industrial revolution occurred four times, culminating in the 2000s, technology, interconnection, and data analysis developed rapidly which gave rise to the idea that all technology be integrated into various industrial fields.

There are four industrial design principles 4.0 (Herman et al., 2015): First, interconnection (connection). Second, transparent information. Third, technical assistance. Fourth, decentralized decisions. Industry 4.0 has a significant impact on various aspects 
such as management science, education, labor market, society and according to Horváth \& Szabó (2019) also for manufacturing companies. Hüther (2016) argued that the possibility of change can put pressure on policies, economic regulators and also new skills and competencies needed by new technology will require changes in the education system. Social cohesion can be weakened if technological change is not accompanied by significant changes in the socio-economic system (Vacek, 2017). Therefore, Szabó et al. (2019) argues that Industry 4.0 is a socio-economic and technological phenomenon.

The higher education policy deals with how universities organized, operated and funded. It must bring the disruptive effect in this digital era. For campuses that are not ready, they will not be able to catch up. Higher education policy must also touch to various sides starting from the philosophical and technical sides. Universities are required to keep up to date in order to be able to keep up with the demands of the industrial revolution 4.0.

Management referred to knowing what you wanted to do and then monitoring it in the best way (Drucker, 1998, 2009). Since then, management theory evolved which consists of two parts of the essence of management, physical and conceptual (Freedman, 1992). Management is a combination of various components or scientific disciplines and management is the key to economic progress (Alford, 1951; Drucker, 1998; Wrege \& Greenwood, 1991).

The entry of the 4.0 industrial revolution era, various scientific disciplines, particularly management science, and higher education policy, experienced adjustments and changes. Therefore, it is crucial for researchers to investigate how the development of higher education policy and management science in the era of the industrial revolution 4.0. From the review of several articles and from the best of author knowledge, the author has not found a article specifically discusses the role of higher education policy and the development of management science in the industrial revolution 4.0.

The main purpose of this article is to review the role of higher education policy and development of management science in the era of the industrial revolution 4.0. Based on the evolutionary concept of management processes, this article aims to focus on how the industrial revolution has influenced higher education policy and management science. Furthermore, this letter will summarize the discussion about the concept of industry 4.0, the evolution of management science by including the origin of management and its progress during industrialization. Finally, the role of human resources and management science curriculum in the industrial revolution 4.0 era, the role of higher education policy and the direction of the development of management science will also be discussed. 


\section{LITERATURE REVIEW}

\section{Industrial 4.0 Concept}

The end of the 18th century was the beginning of the industrial revolution when mechanical production facilities powered by water and steam were first used in the world. The second industrial revolution began when mass production became possible with the use of electricity and the distribution of labor in the early 20th century. Several scholars (Ghobakhloo, 2018; Kagermann et al., 2013; Shrouf et al., 2014) argued that third industrial revolution marked by a higher degree of automation of production and different work processes and achieved through information technology industries and application of electronic. Furthermore, the fourth industrial revolution was considered a result of the horizontal expansion of information technology (Lee et al., 2018). Communication technology and information is widely used in various fields, including government, business and everyday life (Kovács, 2017a) and according to Aichholzer et al. (2015), interconnection is a fundamental element.

According to Buhr (2017), the industrial concept 4.0 was introduced in 2011 by the German Industry-Science Research Alliance. Dorst et al. (2015) and Spath et al. (2013) argued that the term industry 4.0 describes an increase in digitization of the entire supply chain and resulted in connecting actors, systems, and objects based on real-time data exchange. As a result of this interconnection, machines, processes, and products with artificial intelligence will be able to adapt to changing environments (Hecklau et al., 2016).

Moreover, Posada et al. (2015) and Roblek et al. (2016) define five key elements of Industry 4.0 consisted of (1) digitization, customization and optimization of production; (2) adaptation and automation; (3) human and machine interaction; (4) value-added and storing services, and (5) automatic data exchange and communication.

Zezulka et al. (2016) proposed that industry term 4.0 is used for three factors: (1) digitization and network integration, (2) digitization of products and services, and (3) new market models. There are four main elements of Industry 4.0 as identified by Hermann et al. (2015), namely the physical cyber system, the Internet of Things (IoT), internet services and smart factories. In addition, Industry 4.0's main features are virtualization, interoperability, automation, flexibility, real time availability, service orientation, and energy efficiency as defined by Perales et al. (2018). 


\section{The history of management and the industrial revolution}

According to Drucker (2009) and Greenwood (1999), the history of management is as old as humans and management has existed for thousands of years. The tangible evidence that depicts management is the Egyptian pyramid and the Great Wall of China (Argyris, 1965; Drucker, 1998). In 1776, Adam Smith is the first oversaw the efforts of various manufacturing techniques and considered laid a milestone towards management (Sheldrake, 2003; Van Der Aalst et al., 2003; Wrege \& Greenwood, 1991; Wren \& Bedeian, 1994). Adam Smith argued that the community will benefit economically if each job assigned to workers is broken down into a variety of repetitive tasks that are tapered (Hofstede, 1994; Lawler, 1973; Light et al., 1995). Furthermore, Adam Smith focused on concepts and problems related to management processes to increase motivation among workers (Frey \& Osterloh, 2002; Sheldrake, 2003).

Adam Smith argues that the division of labor leads to efficient production (Davis \& Naumann, 1999) and the level of productivity increased by responsive knowledge about tasks (Rosenberg, 1965). The time paradigm shifted agricultural economics towards mechanical economics in the 15th century (Nicholson, 2011). During the industrial revolution, people felt it was more economical to produce products in factories than at home (Armitage, 2000). Most researchers (Sheldrake, 2003; Van Der Aalst et al., 2003; Wren \& Bedeian, 1994) suggest that the industrial revolution served as the most important turning point in the past. Berman (1992) and Cooper \& Burrell (1988) urged that the industrial revolution almost affected every trait of daily life in various ways. The standard of living of the general population began to experience constant growth and this happened for the first time in history (Sheldrake, 2003; Van Der Aalst et al., 2003; Wren \& Bedeian, 1994). Jones (2001) and Wrege \& Greenwood (1991) argued the need for a comprehensive approach to management thinking sparked a journey to modern management after the industrial revolution.

Furthermore, the foundation of scientific management is laid by Frederick W. Taylor and it was based on the classical management theory (Aufhauser, 1973; Freedman, 1992; Freeman \& Louçã, 2002). According Jones et al. (2003), Frederick Taylor introduces the concept of scientific management that influences management thought processes on a fairly large scale. Frederick Taylor found that workers' abilities could be improved and the economy could obtain substantial growth by using scientific procedures and methods (Freedman, 1992). Drucker (1998) argued that the scientific management principles introduced by Frederick Taylor are widely applied throughout the industry to increase 
organizational productivity. The purpose of scientific management is to create knowledge about how to develop work processes although the archetypal application of scientific management in manufacturing (Taylor, 2013; Wrege \& Greenwood, 1991; Wren \& Bedeian, 1994).

Weber's contribution is a characteristic framework referred to as "bureaucracy" and his contribution to management thinking is truly bureaucratic (Joerges \& Czamiawska, 1998; Swedberg, 2000). According to Weber, society is increasingly industrialized (Käsler, 1988) and the goals of creation and industrial goals are also increasingly complex with rapid innovation (Rappa, 2003). According to Morgan (1989), bureaucracy shows that management styles must be hierarchical and to achieve a certain level of work skills, people must obey the order of legitimate authority (Rothschild-Whitt, 1979). Clegg (1990) suggested that the emphasis of the bureaucracy is on legal authority and the obstacles behind legal authority are to ensure treatment and equal opportunity for all (Handel, 2003). Argyris (1965) and Satow (1975) argued that organizations as machines act as rational companies. In addition, achievements and associations that connect divisions and places are intended to make work as efficient as possible (Alford, 1951; Bennis, 1966; Berman, 1992; Morgan, 1982). In Weber's view, bureaucracy acts as a model in the organizing industry (Engel, 1970). Bureaucratic management functions as a major feature in modern society (Blau, 1956) and during the industrial revolution it was considered rational and efficient (Handelman, 1981) although bureaucratic management is subject to various criticisms (Hodgson, 2004).

\section{RESEARCH METHOD}

This article used qualitative methods with a phenomenological approach. According to Creswell 1998), phenomenological studies describe an experience or phenomenon. Data collection is carried out by means of literature study and also using document study data collection methods. The data collected consists of secondary data and obtained through the study of literature.

Secondary data collection used in this study is the literature study which includes secondary data collection obtained from the relevant articles and books. According to Nazir (2013) data collection techniques by conducting a study of reviewers of books, literature, notes, and previous reports relating to the problem being studied. 


\section{RESULTS}

\section{The role of human resources and management science curriculum in the industrial revolution 4.0}

In a world of industrial revolution 4.0, it is required individuals who possess creative and innovative qualities. Qualified individuals are human beings who have positive competitiveness who can later produce a work or product that can compete globally. One effort that can be done to improve the quality of individuals is the use of educational technology that requires fundamental changes in the education system. This fundamental change is related to curriculum policy, especially management science, because the curriculum is a reference used in learning and training in education and/or training which in its development involves philosophical thinking, psychology, science, technology, social and culture. This management science curriculum must be able to direct and shape higher education students who are ready to face the era of the industrial revolution 4.0 with an emphasis on the fields of Science, Technology, Engineering, and Mathematics (STEM).

In addition, reorienting the development of the management science curriculum at the university must also refer to learning based on the Internet of Things, ICT, big data, computerization, and entrepreneurship. Universities in Indonesia that are also experiencing the rapid development of the industrial revolution 4.0 must be able to adapt and innovate by emphasizing the development of human resources (the university academic community) and specifically the management science curriculum. So that all the academic community and management science curriculum with an emphasis on the fields of Science, Technology, Engineering, and Mathematics (STEM) can be one of the drivers of the industrial movement, especially higher education in order to have competitiveness and achieve high productivity in the global era.

\section{The role of higher education policy in the era of the industrial revolution 4.0}

Higher education policies must be able to encourage economic growth and national competitiveness in the era of the industrial revolution 4.0. Furthermore, the higher education policy must be able to produce two outcomes or achievements that are fulfilled by universities, namely publication in Scopus indexed journals or the like. The second is regarding the absorption of alumni by working world and will later become a disruption effect for universities if they do not have a systemic mechanism in tracking the whereabouts of alumni (tracer study). The policy will also encourage universities to 
strengthen networking with the business and industry world to ensure the certainty of their alumni is absorbed.

Besides networking with outsiders, universities themselves also need to be creative in building an entrepreneurial ecosystem as well as an industrial and business world that is used by students, at least for an apprenticeship, if as a target the workplace cannot be optimized. The entrepreneurial ecosystem needs to start with curriculum design. The Government of Indonesia has issued a policy on developing a curriculum called KPT (higher education curriculum) which is equipped with guidelines for its preparation. In the higher education curriculum, it is clear that it has the spirit of link and match with the industrial revolution 4.0.

\section{The development of management science in the industrial revolution 4.0}

Management science today is the work of research conducted by various researchers including Adam Smith which introduced the principles of division of labor for the first time to increase worker productivity with efficiency. Nowadays, management theories are being and have been used in various industries to discuss the phenomenon of productivity of management thinking which is at the heart of organizational performance. A major step towards management progress occurred during the industrial revolution. Furthermore, the main contribution to management thinking is the result of logic during the era of modernism and industrial development during industrialization. The management principles developed by Adam Smith place the foundation of the management thought process. Moreover, the scientific management theory proposed by Fredrick W. Taylor and the bureaucratic theory proposed by Max Weber is still practiced today in the industry as a model that is used as a reference by researchers (Ayesha, 2015).

The direction of the development of management science including marketing management, operational management, human resource management (people management), financial management and strategic management must emphasize in the fields of Science, Technology, Engineering, and Mathematics (STEM). In addition, management science is expected to be able to create higher thinking order skills (HOTS), especially for higher education students. According to Bloom's Taxonomy introduced by Benjamin S. Bloom in 1956, cognitive processes are divided into lower-order thinking abilities (LOT) and higher-order thinking abilities (HOT). Abilities that include LOT are the ability to remember, understand and apply, while HOT includes the ability to analyze, evaluate and create. 
In term of journals publication, several researchers have investigated the links between the industrial revolution 4.0 and various derivatives of management science. For example, Liboni et al. (2019) investigated the potential impact of industry 4.0 on human resource management $(\mathrm{HR})$ - with a special focus on employment, job profiles and qualifications and skills requirements in the workforce - which could have implications for supply chain management (SCM). Furthermore, Ardito et al. (2019) also presents a comprehensive picture of innovative efforts made in developing digital technology to manage the interface between supply chain management and marketing processes (Supply Chain Management - Marketing). In the era of the industrial revolution 4.0 which is dominated by technology, artificial intelligence, and robots, the management science teaching must be using the latest technology. Furthermore, management science must also provide teaching of noble values, spiritual values, wisdom and also the element of human touch for both lecturers and students.

\section{CONCLUSION}

The industrial revolution is an era of innovation and technology that spread not only in the European economy but also throughout the world in its early days. The era of the industrial revolution not only leads to technological innovation but also to new management prospects. Over time, the range of management knowledge continues to move forward. During the industrial revolution, the scientific principles of management and the bureaucratic style add a significant contribution to the management thought process and worker productivity.

The era of the industrial revolution 4.0 has changed the way of thinking about management science. More important changes are changes in the perspective of the concept of management science itself. The management science curriculum developed must be able to direct and shape students who are ready to face the era of the industrial revolution with an emphasis on the fields of Science, Technology, Engineering, and Mathematics (STEM). Management science must already refer to ICT-based learning, the Internet of Things, big data and computerization to produce graduates who are able to compete in this unlimited global era. The academic community must also understand how education and learning are organized, namely student-centered learning, collaborative learning, meaningful learning and integrated with the community.

The presence of the industrial revolution 4.0 has produced new business concepts, new jobs, and new professions. However, with the passage of time and the development of 
technological empowerment, it could be that business concepts that have been built with professions and jobs will now be replaced by robots and artificial intelligence machines. This due to the development of industrial revolution 4.0 is more focused on digital lifestyle, thinking tools, learning research and the workings of knowledge. A unique characteristic in the industrial revolution 4.0 is the application of artificial intelligence in the form of robots used as a substitute for human power. This technological advancement enables the use of technology in all fields, without exception in management science. Therefore, management science must align with the industrial revolution 4.0 to remain relevant to the business or industrial world, the world of teaching or education, the world of research and community service now and in the future.

Strategic policies need to be formulated in various aspects ranging from institutions, fields of study, curriculum, resources, and development of research to innovation. Reconstruction of higher education institutional policies that are responsive and adaptive to the industrial revolution 4.0 in developing the transdisciplinary science and study programs needed. Also, the development of a distance learning system, hence reducing the intensity of lecturer and student meetings. This is later expected to be a solution for students in remote areas to reach high quality higher education.

The role of lecturers in the development of management science in the industrial revolution 4.0 era is also crucial. Millennials are expected to be lecturers and demanded to be more competitive and up to date in this VUCA world. There are five lecturer qualifications and competencies needed in the industrial revolution era 4.0, including (1) educational competence, (2) competence in research, (3) competence for technological commercialization, (4) competence in globalization, and (5) competence in future strategies, (Retrieved January 21, 2020, from http://sumberdaya.ristekdikti.go.id/index.php/2018/01/30/era-revolusi-industri-4-0saatnya-generasi-millennial-menjadi-dosen- future/).

In the era of the industrial revolution 4.0 which is dominated by technology, artificial intelligence, and robots, in addition to teaching management science using the latest technology, management science must also be a pioneer in producing academics who have noble values, spiritual values, wisdom and also the element of human touch. 


\section{RECOMMENDATION}

Based on the conclusions, some suggestions that can be considered are:

1. Future articles are suggested to focus on the direction of the development of management science in the industrial revolution era 1.0, 2.0 and 3.0.

2. Future articles are intended to conduct an empirical test of the direction of the development of management science in the era of the industrial revolution 4.0 by using mix methods which can be started with qualitative methods (focus group discussion or in-depth interviews) then followed by quantitative methods (survey or experiment).

\section{REFERENCES}

Aichholzer, G., Gudowsky, N., Saurwein, F., Weber, M. (2015). Industry 4.0. Background Paper on the Pilot Project "Industry 4.0. Foresight \& Technology Assessment on the Social Dimension of the Next Industrial Revolution". (Vienna).

Alford, L. P. (1951). Principles of industrial management: Ronald Press Company.

Ardito, L., Petruzzelli, A.M., Panniello, U., Garavelli, A.C. (2019). Towards Industry 4.0: Mapping digital technologies for supply chain management-marketing integration. Business Process Management Journal, Vol. 25 No. 2, 323-346.

Argyris, C. (1965). Organization and innovation: RD Irwin.

Armitage, J. (2000). From modernism to hypermodernism and beyond. Paul Virilio: From Modernism to Hypermodernism and Beyond, 25.

Aufhauser, R. K. (1973). Slavery and scientific management. The Journal of Economic History, 33(4), 811-824.

Ayesha, G. (2015). Impact of Industrial Revolution on Management Thought. Sukkur Institute of Business Administration, 2, 1, 1-16.

Bennis, W. G. (1966). Changing organizations. The Journal of Applied Behavioral Science, 2(3), 247-263.

Berman, M. (1992). Why modernism still matters. Modernity and identity, 33-58.

Blau, P. M. (1956). Bureaucracy in modern society. Crown Publishing Group/Random House.

Buhr, D. (2015). Social Innovation Policy for Industry 4.0. Tübingen, Germany: Eberhard Karls University of Tübingen.

Clegg, S. (1990). Modern organizations: Organization studies in the postmodern world: Sage. 
Cooper, R., \& Burrell, G. (1988). Modernism, postmodernism and organizational analysis: An introduction. Organization studies, 9(1), 91-112.

Creswell, J.W. (1998). Qualitative Inquiry and Research Design: Choosing among Five Tradition. London: Sage Publications.

Davis, G. B., \& Naumann, J. D. (1999). Knowledge Work Productivity. Emerging information technologies: Improving decisions, co-operation and infrastructure, Sage, London, 343-357.

Dorst, W., Glohr, C., Hahn, T., Knafla, F., Loewen, U., Rosen, R., Schiemann, T., Vollmar, F., Winterhalter, C. (2015). Umsetzungsstrategie Industrie 4.0. Ergebnisbericht der Plattform Industrie 4.0.

Drucker, P. F. (1998). Management's new paradigms. Forbes Magazine, 10, 98.

Drucker, P. F. (2009). Management Rev Ed: Harper Collins.

Engel, G. V. (1970). Professional autonomy and bureaucratic organization. Administrative science quarterly, 12-21.

Freedman, D. H. (1992). Is management still a science? Harvard Business Review, 70 (6), 26-38.

Freeman, C., \& Louçã, F. (2002). As time goes by: from the industrial revolutions to the information revolution. OUP Catalogue.

Frey, B. S., \& Osterloh, M. (2002). Successful management by motivation: Balancing intrinsic and extrinsic incentives: Springer.

Ghobakhloo, M. (2018). The future of manufacturing industry: a strategic roadmap toward Industry 4.0. Journal of Manufacturing Technolony Management, 29, 910-936.

Greenwood, J. (1999). The third Industrial Revolution: Technology, productivity, and income inequality. Economic Review, 35 (1).

Handel, M. J. (2003). The sociology of organizations: Classic, contemporary, and critical readings: Sage.

Handelman, D. (1981). Introduction: the idea of bureaucratic organization. Social Analysis, (9), 5-23.

Hecklau, F., Galeitzke, M., Flachs, S., Kohl, H. (2016). Holistic approach for human resource Management in Industry 4.0. Procedia CIRP, 54, 1-6. https://doi.org/10.1016/j.procir.2016.05.102

Hermann, M., Pentek, T., Otto, B. (2015). Design Principles for Industry 4.0 Scenarios: A Literature Review. 
Hodgson, D. E. (2004). Project work: the legacy of bureaucratic control in the postbureaucratic organization. Organization, 11(1), 81-100.

Hofstede, G. (1994). Management scientists are human. Management science, 40 (1), 4-13.

Horváth, D. \& Szabó, Z. R. (2019). Driving forces and barriers of Industry 4.0: Do multinational and small and medium-sized companies have equal opportunities?. Technological Forecasting \& Social Change, 146, 119-132.

Hüther, M. (2016). Digitalisation: An Engine for Structural Change - A Challenge for Economic Policy (No. IW Policy Paper·15/2016). (Köln).

Jones, C. I. (2001). Was an industrial revolution inevitable? Economic growth over the very long run. Advances in Macroeconomics, 1 (2).

Jones, G. R., George, J. M., \& Hill, C. W. (2003). Contemporary management: McGrawHill/Irwin New York.

Joerges, B., \& Czamiawska, B. (1998). The question of technology, or how organizations inscribe the world. Organization studies, 19 (3), 363-385.

Kagermann, H., Wahlster, W., Helbig, J. (2013). Recommendations for Implementing the Strategic Initiative Industrie 4.0.

Käsler, D. (1988). Max Weber: University of Chicago Press.

Kemenristekdikti (2018, January 30). Era Revolusi Industri 4.0, Saatnya Generasi Millennial Menjadi Dosen Masa Depan. Retrieved January 21, 2020 from [http://sumberdaya.ristekdikti.go.id/index.php/2018/01/30/era-revolusi-industri-4-0saatnya-generasi-millennial-menjadi-dosen-masa-depan/.

Kovács, O. (2017a). Az ipar 4.0 komplexitása - II. Közgazdasági Szle, 64, 970-987. https://doi.org/https://doi.org/10.18414/KSZ.2017.9.970.

Lawler, E. (1973). Motivation in Work Organizations. Monterey, CA: Brooks/Cole.

Lee, M., Yun, J.J., Pyke, A., Won, D., Kodama, F., Giovanni, Schiuma, Park, H., Jeon, J., Park, K., Jung, K., Yan, M.-R., Lee, S., Zhao, X. (2018). How to respond to the fourth industrial revolution, or the second information technology revolution? Dynamic new combinations between technology, market, and society through open innovation. J. Open Innov. 4, 1-24. https://doi.org/10.3390/joitmc4030021.

Liboni, L.B., Cezarino, L.O., Jabbour, C.J.C., Oliveira, B.G., Stefanelli, N.O. (2019). Smart industry and the pathways to HRM 4.0: implications for SCM. Supply Chain Management: An International Journal, 24/1, 124-146.

Light, S. S., Gunderson, L. H., \& Holling, C. (1995). The Everglades: evolution of management in a turbulent ecosystem. Barriers and Bridges to the Renewal of Ecosystems and Institutions, 103-168. 
Morgan, G. (1982). Cybernetics and organization theory: epistemology or technique? Human Relations, 35(7), 521-537.

Morgan, G. (1989). Creative organization theory: A resourcebook: Sage.

Nazir, M. (2013). Metode Penelitian. Bogor: Ghalia Indonesia.

Nicholson, J. (2011). The Industrial Revolution and Beyond. The Gifts of Athena: Historical Origins of the Knowledge Economy, 78.

Perales, D.P., Valero, F.A., García, A.B. (2018). Industry 4.0: a classification scheme. In: Viles, E., Ormazábal, M., Lleó, A. (Eds.), Closing the Gap between Practice and Research in Industrial Engineering. Lecture Notes in Management and Industrial Engineering. Springer, Cham, pp. 343-350.

Posada, J., Toro, C., Barandiaran, I., Oyarzun, D., Stricker, D., Amicis, de R., Pinto, B.E., Eisert, P., Döllner, J., Vallarino, I. (2015). Visual computing as a key enabling technology for Industrie 4.0 and industrial internet. IEE Comput. Graph. Appl. 35, 26-40.

Rappa, A. L. (2003). A Critique of Modernity: On Positivism, and Phenomenology. Alternatives: Turkish Journal of International Relations, 2 (3-4).

Roblek, V., Mesko, M., Krapez, A. (2016). A complex view of industry 4.0. SAGE Open 6.

Rosenberg, N. (1965). Adam Smith on the division of labour: two views or one? Economica, 32 (126), 127-139.

Rothschild-Whitt, J. (1979). The collectivist organization: An alternative to rationalbureaucratic models. American Sociological Review, 509-527.

Satow, R. L. (1975). Value-rational authority and professional organizations: Weber's missing type. Administrative science quarterly, 526-531.

Sheldrake, J. (2003). Management theory: Cengage Learning EMEA.

Shrouf, F., Ordieres, J., Miragliotta, G. (2014). Smart factories in industry 4.0: a review of the concept and of energy management approached in production based on the internet of things paradigm. In: Proceedings of the 2014 IEEE IEEM, pp. 697-701. Selangor Darul Ehsan, Malaysia.

Spath, D., Ganschar, O., Gerlach, S., Hämmerle, M., Krause, T., Schlund, S. (2013). Produktionsarbeit der Zukunft-Industrie 4.0. (Stuttgart).

Swedberg, R. (2000). Max Weber and the idea of economic sociology: Princeton University Press. 
Szabó, Z.R., Horváth, D., Hortoványi, L. (2019). Hálózati tanulás az ipar 4.0 korában. Közgazdasági Szle. 66, 72-94. https://doi.org/http://dx.doi.org/10.18414/Ksz. 2019.1.72.

Taylor, F. W. (2013). Scientific management: Routledge.

Vacek, J. (2017). On the road: from industry 4.0 to society 4.0. Trendy v Podn 7, 43-49.

Van Der Aalst, W. M., Ter Hofstede, A. H., \& Weske, M. (2003). Business process management: A survey: Springer.

Wrege, C. D., \& Greenwood, R. G. (1991). Frederick W. Taylor, the father of scientific management: myth and reality: Irwin Professional Pub.

Wren, D. A., \& Bedeian, A. G. (1994). The evolution of management thought. John Wiley \& Sons, Inc.

Zezulka, F., Marcon, P., Vesely, I., Sajdl, O., 2016. Industry 4.0 - an introduction in the phenomenon. IFAC-PapersOnLine 49, 8-12. 